\title{
Fischer-Tropsch products from biomass-derived syngas and renewable hydrogen
}

\author{
Hannes Gruber ${ }^{1,2}$ (1) $\cdot$ Peter Groß ${ }^{1} \cdot$ Reinhard Rauch $^{2,3} \cdot$ Alexander Reichhold $^{1} \cdot$ Richard Zweiler $^{4}$. \\ Christian Aichernig ${ }^{5} \cdot$ Stefan Müller ${ }^{6} \cdot$ Nabeel Ataimisch $^{7} \cdot$ Hermann Hofbauer $^{1,2}$
}

Received: 29 March 2019 / Revised: 31 May 2019 / Accepted: 4 June 2019 / Published online: 22 June 2019

(C) The Author(s) 2019

\begin{abstract}
Global climate change will make it necessary to transform transportation and mobility away from what we know now towards a sustainable, flexible, and dynamic sector. A severe reduction of fossil-based $\mathrm{CO}_{2}$ emissions in all energy-consuming sectors will be necessary to keep global warming below $2{ }^{\circ} \mathrm{C}$ above preindustrial levels. Thus, long-distance transportation will have to increase the share of renewable fuel consumed until alternative powertrains are ready to step in. Additionally, it is predicted that the share of renewables in the power generation sector grows worldwide. Thus, the need to store the excess electricity produced by fluctuating renewable sources is going to grow alike. The "Winddiesel" technology enables the integrative use of excess electricity combined with biomass-based fuel production. Surplus electricity can be converted to $\mathrm{H}_{2}$ via electrolysis in a first step. The fluctuating $\mathrm{H}_{2}$ source is combined with biomass-derived CO-rich syngas from gasification of lignocellulosic feedstock. Fischer-Tropsch synthesis converts the syngas to renewable hydrocarbons. This research article summarizes the experiments performed and presents new insights regarding the effects of load changes on the Fischer-Tropsch synthesis. Long-term campaigns were carried out, and performance-indicating parameters such as per-pass $\mathrm{CO}$ conversion, product distribution, and productivity were evaluated. The experiments showed that integrating renewable $\mathrm{H}_{2}$ into a biomass-to-liquid Fischer-Tropsch concept could increase the productivity while product distribution remains almost the same. Furthermore, the economic assessment performed indicates good preconditions towards commercialization of the proposed system.
\end{abstract}

Keywords Fischer-Tropsch synthesis $\cdot \mathrm{BtL} \cdot$ Energy storage $\cdot$ Excess electricity $\cdot$ ASF distribution $\cdot$ Economic assessment

Abbreviations
\begin{tabular}{ll} 
FT & Fischer-Tropsch \\
FTS & Fischer-Tropsch synthesis \\
$1 \mathrm{H}$ & hydrogen-nuclear magnetic resonance \\
NMR & spectroscopy \\
\hline
\end{tabular}

Hannes Gruber

hannes.gruber@tuwien.ac.at

1 Institute of Chemical, Environmental \& Biological Engineering, TU Wien, Vienna, Austria

2 Bioenergy 2020+, Güssing, Austria

3 Engler-Bunte-Institut, Karlsruhe Institute of Technology, Karlsruhe, Germany

4 Güssing Energy Technologies GmbH, Güssing, Austria

5 Aichernig Engineering $\mathrm{GmbH}$, Vienna, Austria

6 EC Engineering GmbH, Vienna, Austria

7 Bilfinger Bohr- und Rohrtechnik GmbH, Vienna, Austria

$\begin{array}{ll}\text { BtL } & \text { biomass-to-liquid } \\ \text { PtG } & \text { power-to-gas } \\ \text { ICE } & \text { internal combustion engines } \\ \text { HC } & \text { hydrocarbon } \\ \text { C }_{n} & \text { hydrocarbon with } n \text { carbon atoms } \\ \text { DFB } & \text { dual fluidized bed } \\ \text { BTX } & \text { benzene, toluene, xylene } \\ \text { SV } & \text { space velocity } \\ \text { Nl } & \text { standard liter } \\ \text { Nm } & \text { standard cubic meter } \\ \text { h } & \text { hour } \\ \text { SBCR } & \text { slurry bubble column reactor } \\ \text { P/O } & \text { paraffin/olefin ratio by weight } \\ \text { ASF } & \text { Anderson-Schulz-Flory } \\ \text { RWGS } & \text { reverse water-gas shift } \\ \text { GC } & \text { gas chromatography } \\ \text { FID } & \text { flame ionization detector } \\ \text { TCD } & \text { thermal conductivity detector } \\ \text { ROI } & \text { return on investment } \\ & \end{array}$




\section{Introduction}

\subsection{The need for decarbonization}

At this year's United Nations Framework Convention on Climate Change Conference, a strategy for a functional Paris agreement was negotiated. It is going to be challenging to limit global warming to 1.5 or $2{ }^{\circ} \mathrm{C}$ above preindustrial levels, as proposed by the Paris Agreement. Today, anthropogenic global warming accounts already for about $1{ }^{\circ} \mathrm{C}$, reaching $1.5{ }^{\circ} \mathrm{C}$ between 2030 and 2050 . To reach either of these climate goals, net zero for anthropogenic $\mathrm{CO}_{2}$ emissions needs to be accomplished in this century $[1,2]$.

In Germany, the share of renewable energy consumed by transportation settled to $5.2 \%$ with stagnating tendencies in 2017. Compared to 2007 rates $(7.5 \%$ ), a decrease was observed in this regard. On the other hand, the renewable share of gross electricity consumed increased at a high pace from $14.3 \%$ in 2007 to $36.2 \%$ in 2017 [3].

Thus, a high potential to reduce fossil $\mathrm{CO}_{2}$ emissions in transportation is evident. Fischer-Tropsch synthesis (FTS) produces hydrocarbons ranging from $\mathrm{CH}_{4}$ to hydrocarbons with more than 60 carbon atoms. The products of an integrated FTS biorefinery designed to produce renewable transportation fuel could be premium diesel and kerosene [4, 5]. Feasible upgrading steps and final applications of these renewable fuels derived by FTS were discussed in complementary literature [4-13].

The addition of renewable power production capacities is predicted to increase in the next years [14]. This expansion will correlate with the availability of fluctuating excess electricity. Power-to-gas $(\mathrm{PtG})$ systems are a suitable technology to convert and subsequently store excess electricity [15]. Gahleitner [16] gives an overview on realized PtG facilities. One of the main issues regarding the quick integration of $\mathrm{H}_{2}$ or $\mathrm{CH}_{4}$, produced via $\mathrm{PtG}$ technologies, as transportation fuel is the lack of cars powered with these fuels. In Germany, over 45 million registered vehicles are powered by diesel or gasoline, whereas less than one million are powered by alternative power trains, in 2018 [17]. Even though new legislation may benefit the development and distribution of alterative powertrains, a complete shift away from internal combustion engines (ICE) will take time. To reach a rapid reduction of $\mathrm{CO}_{2}$ emissions in transportation, alternative fuels will be needed to power existing ICEs. The Winddiesel technology provides a solution to this dilemma. Groß et al. [18] presented the concept in 2015. The basic idea of this technology is shown in Fig. 1. Biomass gasification, using $\mathrm{CO}_{2}$ and steam as gasification agent, produces CO-rich product gas [19-22]. $\mathrm{CO}_{2}$ is removed from the product gas stream. If excess electricity is available, $\mathrm{CO}_{2}$ is recycled as gasification agent to the gasifier promoting the reverse water-gas shift (RWGS) reaction. $\mathrm{CO}_{2}$ that is not fed to the gasifier might be utilized using a RWGS unit as proposed by Pastor-Pérez et al. [23]. $\mathrm{H}_{2}$, produced by excess electricity, is mixed with the CO-rich product gas from biomass gasification. Subsequently, FTS is applied to convert the cleaned and conditioned syngas to hydrocarbons. If integrated without storage capacities, the fluctuating $\mathrm{H}_{2}$ implies load changes to FTS. Compared to a conventional biomass-toliquid (BtL) FT concept, the FT capacity is enlarged, an electrolyzer is added to enable the utilization of excess electricity, and $\mathrm{CO}_{2}$ is recycled. The desired products naphtha, diesel, and wax are fractionated and if required refined. After purification, the product water can be recycled as feed for electrolysis.

Müller et al. [24] validated experimental data using process simulation. This investigation showed that the integration of renewable $\mathrm{H}_{2}$ produced by excess electricity into FTS fuel production is a suitable possibility to store energy. Further investigation regarding efficiency and economic aspects regarding Winddiesel were proposed. Nikparsa et al. [25] investigated FT syncrude regarding olefin distribution using ${ }^{1} \mathrm{H}$ NMR technology.

This work is a summary and review of experimental and economic data published so far in the course of the Winddiesel project. Additionally, new aspects regarding substance-class distribution of FTS syncrude, effects of load changes on productivity, and economic aspects were added and discussed.

\subsection{Why Fischer-Tropsch synthesis?}

First insights on the hydrogenation of $\mathrm{CO}$ were reported by Sabatier et al. [26] in 1902. Subsequently, Fischer and Tropsch [27] described the production of synthetic oil from $\mathrm{CO}$ and $\mathrm{H}_{2}$. Later research and the commercialization are summarized by Steynberg [28]. FTS produces a mixture of hydrocarbons (syncrude) with different chain lengths. The catalytic conversion of $\mathrm{H}_{2}$ and $\mathrm{CO}$ to hydrocarbons is described as stepwise reaction. $\mathrm{CH}_{2}$ intermediates (Eq. 1) are formed from $\mathrm{H}_{2}$ and CO. The chain growth and the production of paraffins (Eq. 2), olefins (Eq. 3), and oxygen-containing components by FTS are summarized by Schulz [29]. Further summaries regarding FT reactions were published by other authors [30, 31].

$$
\begin{aligned}
& 2 \mathrm{H}_{2}+\mathrm{CO} \rightarrow\left(\mathrm{CH}_{2}\right)+\mathrm{H}_{2} \mathrm{O} \\
& (2 \mathrm{n}+1) \mathrm{H}_{2}+\mathrm{nCO} \rightarrow \mathrm{C}_{\mathrm{n}} \mathrm{H}_{2 n+2}+\mathrm{nH}_{2} \mathrm{O} \\
& (2 \mathrm{n}) \mathrm{H}_{2}+\mathrm{nCO} \rightarrow \mathrm{C}_{\mathrm{n}} \mathrm{H}_{2} \mathrm{n}+\mathrm{nH}_{2} \mathrm{O}
\end{aligned}
$$

The Anderson-Schulz-Flory (ASF) distribution describes the distribution of FT products. De Klerk [31] described the ASF distribution and summarized deviations from it. The mass fraction $W_{n}$ of hydrocarbons with $n$ carbon atoms can be determined experimentally by gas chromatography. Subsequently, the chain growth parameter $\alpha$ can be 


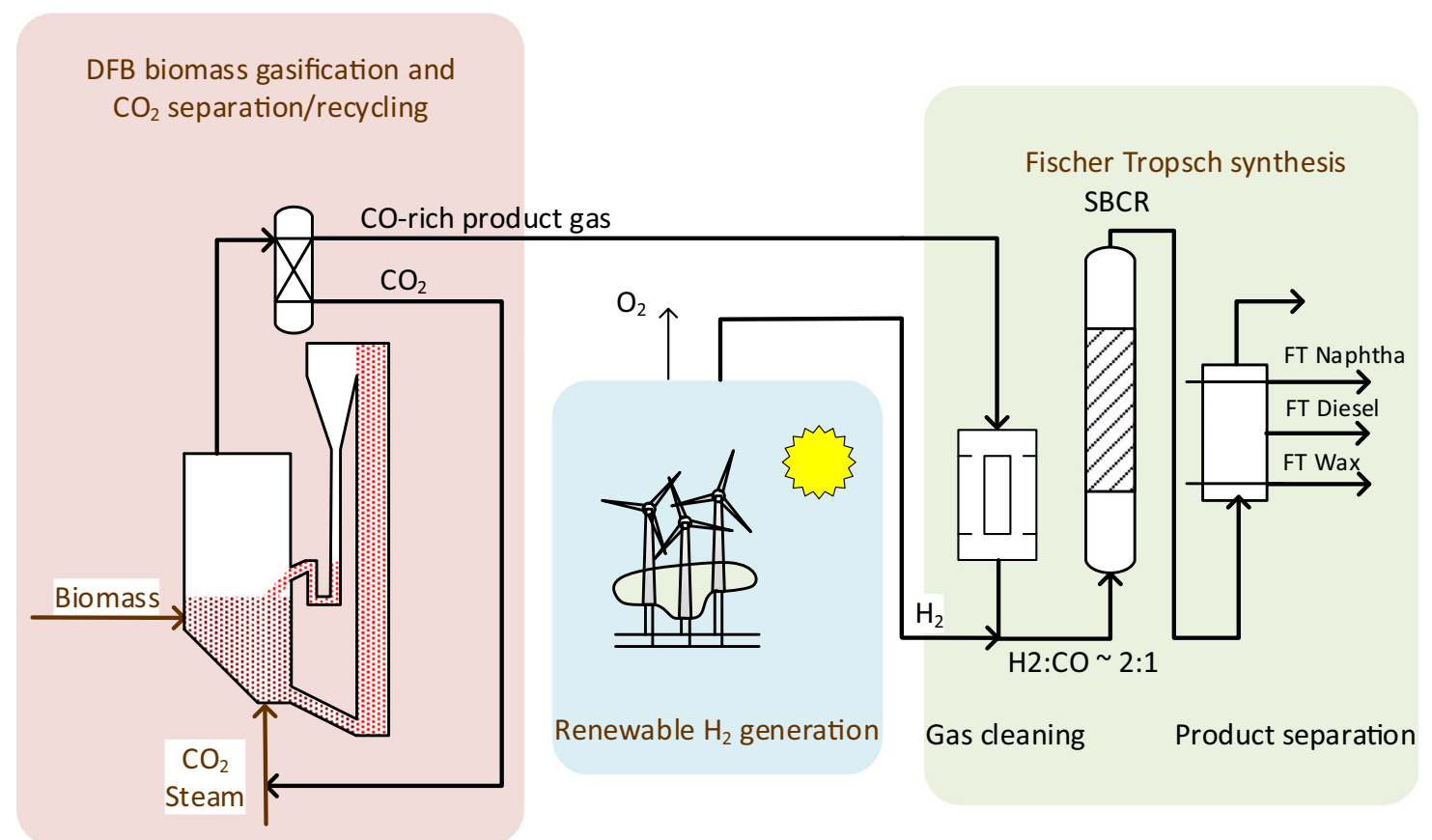

Fig. 1 Basic concept of the "Winddiesel" technology

determined from the straight-line proportion of the ASF plot using Eq. 4 [32].

$\log \left(\frac{W_{n}}{n}\right)=n \cdot \log (\alpha)+\log \frac{(1-\alpha)^{2}}{\alpha}$

Anderson [30] gives an overview on suitable catalysts for FTS. Industrial case studies were summarized by Yong-Wang and de Klerk [33]. Possible products from FTS are gasoline, diesel, jet fuel, paraffinic waxes, lubricants, petrochemical base products, and so on [34].

FTS has the capability to convert biomass-based syngas and renewable $\mathrm{H}_{2}$ from excess electricity to hydrocarbons with different chain lengths. The product flexibility might be one of the biggest benefits of FTS. If the production of renewable fuels becomes unprofitable, FT products have other highvalue applications such a 1-olefins [35] (naphtha), white oil blend [36] (diesel), and solid synthetic paraffin [37] (wax). Subsequently, this work summarizes the effects of a varying load on FT performance [24, 38, 39] and presents new insights.

The controversial topic of biomass-based fuels was discussed in literature [40-45]. Different pathways to produce renewable fuels in agreement with current and future legislative and ethic aspects were analyzed. The European Union is currently promoting the production of second-generation biofuels produced from organic residues and waste while at the same time introducing the phasing out of first-generation biofuels $[46,47]$. Alternative substitutions for the farmed wood feedstock, which were used in this investigation, are discussed in the conclusion section.

\section{Experimental}

Seven long-term experimental campaigns were performed at Güssing's biomass conversion research facility. This section gives an overview on materials and methods used to perform and evaluate the experiments.

\subsection{Production of biomass-derived syngas}

The product gas to perform the experiments was provided from the Güssing $8 \mathrm{MW}_{\text {th }}$ biomass steam gasification plant using wood chips as feedstock. At the commercial plant, contaminants like particles, benzene, toluene, xylene (BTX), and tars are reduced to levels suitable for gas engine application. Nevertheless, this gas cleaning is not sufficient for FT synthesis and further cleaning steps were integrated in the FT unit.

Table 1 Ranges of the main components of the product gas [48]

\begin{tabular}{lll}
\hline Component & Unit & Composition \\
\hline $\mathrm{CO}$ & $\mathrm{v} \%$ dry & $20-30$ \\
$\mathrm{H}_{2}$ & $\mathrm{v} \%_{\text {dry }}$ & $35-45$ \\
$\mathrm{CO}_{2}$ & $\mathrm{v} \%_{\text {dry }}$ & $15-25$ \\
$\mathrm{CH}_{4}$ & $\mathrm{v} \%_{\text {dry }}$ & $8-12$ \\
\hline
\end{tabular}


Typical ranges of the main components of the DFB gasifier's product gas are shown in Table 1 [48-50].

\subsection{Fischer-Tropsch laboratory unit}

The laboratory FT unit used to perform the experiments has been continuously improved, integrating know-how of over 10,000 operating hours. Several works $[24,32,38,51-53]$ described the extensive research performed, operating the laboratory FTS unit. The basic flow sheet of the FT unit is shown in Fig. 2. The three main plant sections are as follows.

The gas cleaning and conditioning unit removes tars, BTX, chlorine, and sulfur contaminants from the product gas. Sulfur components are reduced to levels below $10 \mathrm{ppb}$. This is essential to protect the cobalt catalyst, used for FT synthesis, from poisoning. Rauch et al. [54] summarized acceptable levels regarding impurities like sulfur components and alkali metals if cobalt catalysts are used.

The 20-1 slurry bubble column reactor (SBCR) converts $\mathrm{H}_{2}$ and $\mathrm{CO}$ to hydrocarbons with chain lengths ranging from $\mathrm{C}_{1}$ to $>\mathrm{C}_{60}$. The clean syngas enters the three-phase slurry reactor at the bottom. Products and non-converted gaseous components exit the reactor at the top.

The three-step high-pressure product condensation separates liquid FT products and FT water from gaseous components.

The laboratory FT plant is fully automatized. The $\mathrm{H}_{2} / \mathrm{CO}$ ratio is monitored, and adjusted if additional $\mathrm{H}_{2}$ is needed for ideal stoichiometric FTS conditions.

\subsection{Analysis methods}

The inlet and outlet gas composition of the SBCR was measured continuously by gas chromatography (GC). Gaseous hydrocarbons were determined using a flame ionization detector (FID) and other components with a thermal conductivity detector (TCD). GC was also used to analyze liquid and solid
FT products. In-house methods were applied to determine the hydrocarbon distribution. The GC was equipped with a FID and SimDist column. Sauciuc et al. [51] described the analysis method in more detail.

Furthermore, a substance class analysis was carried out. For low-molecular FT syncrude $\left(\mathrm{C}_{6}-\mathrm{C}_{20}\right)$, the content of $\mathrm{n}$ paraffins, 1-olefins, and other hydrocarbons (other $\mathrm{HC}$ ) was determined. The substance class of other HC summarizes iparaffins, oxygenates, and other substance classes. For highermolecular hydrocarbons, it was distinguished between nparaffins and other $\mathrm{HC}$.

The per-pass CO-conversion $\left(X_{\mathrm{CO} \text {,reactor }}\right)$ is defined by Equation 5 [24]. $X_{\mathrm{CO} \text {,reactor }}$ is defined by the quotient of moles of CO consumed by FTS $\left(n_{\mathrm{CO}, \text { in }}-n_{\mathrm{CO} \text {, out }}\right)$ and moles entering the $\operatorname{SBCR}\left(n_{\mathrm{CO}, \text { in }}\right)$.

$X_{\mathrm{CO}, \text { reactor }}=\frac{n_{\mathrm{CO}, \text { in }}-n_{\mathrm{CO}, \text { out }}}{n_{\mathrm{CO}, \text { in }}}$

Note that Gruber et al. [38] defined $X_{\mathrm{CO} \text {,reactor }}$ different to Eq. 5. Additionally, the system productivity regarding condensable FT syncrude ( $\left.\dot{m}_{\mathrm{C} 5+}\right)$ was evaluated (Eq. 6). $\dot{m}_{\mathrm{C} 5+}$ is derived by dividing the sum of naphtha ( $\left.\dot{m}_{\text {naphtha }}\right)$, diesel $\left(\dot{m}_{\text {diesel }}\right)$, and wax $\left(\dot{m}_{\text {wax }}\right)$ mass flow by a mass catalyst $(m-$ catalyst) applied to the system.

$\dot{m}_{\mathrm{C} 5+}=\frac{\dot{m}_{\text {naphtha }}+\dot{m}_{\text {diesel }}+\dot{m}_{\mathrm{wax}}}{m_{\text {catalyst }}}=\sum_{i=5}^{\infty} \dot{m}_{i}$

Furthermore, the n-paraffin to 1-olefin (P/O) ratio (Eq. 7) was determined by the quotient of mass n-paraffin to mass 1 olefin produced per experiment.

$$
P /{ }^{\text {ratio }}=\frac{m_{\mathrm{n}-\text { paraffin }}}{m_{1-\text { olefin }}}
$$

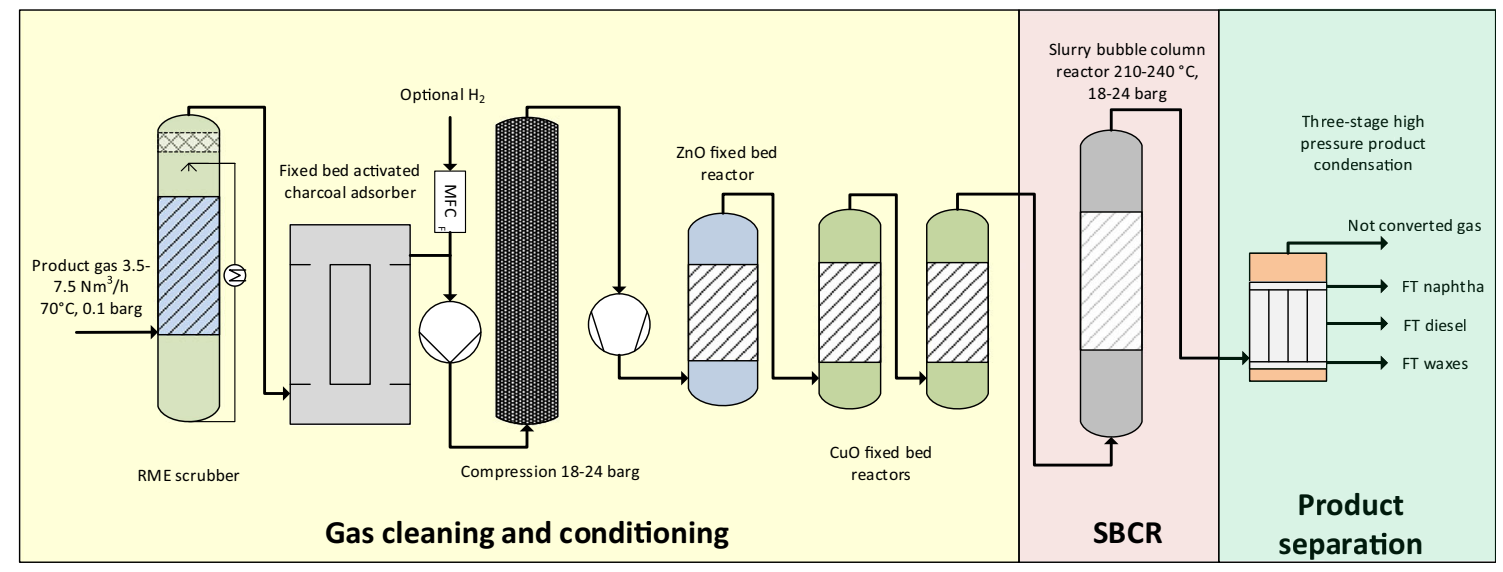

Fig. 2 Basic flowsheet of the laboratory-scale FT unit 


\subsection{Result summary}

The integration and subsequent storing of renewable $\mathrm{H}_{2}$ were investigated by applying load changes to the FT system. Figure 3 shows the volume flow applied to the SBCR simulating low capacity, benchmark operation, peak capacity, and load changes. The SBCR was designed to process 3.5 to $7.5 \mathrm{Nm}^{3} / \mathrm{h}$, having a performance optimum at $5 \mathrm{Nm}^{3} / \mathrm{h}$. Experiments performed at low feed rate $\left(3.5 \mathrm{Nm}^{3} / \mathrm{h}\right)$ simulated low-capacity operation introducing a decreased space velocity (SV) to the synthesis step. Experiments performed at $5 \mathrm{Nm}^{3} / \mathrm{h}$ simulated benchmark operation. The experiments performed at $7.5 \mathrm{Nm}^{3} / \mathrm{h}$ were carried out to evaluate the performance of the SBCR at peak availability of excess electricity. At load change conditions, the feed rate changed its level every $10 \mathrm{~min}$ in the range of 3.5 to $7.5 \mathrm{Nm}^{3} / \mathrm{h}$. Thus, this experimental work evaluated the effects of low capacity, high capacity, and load change operation on the SBCR. Compared to the $5-\mathrm{Nm}^{3} / \mathrm{h}$ benchmark operation, the low-capacity and highcapacity experiments represent a load of $70 \%$ and $150 \%$, respectively.

Table 2 summarizes published experimental results. In total, three campaigns (experiments 2 to 4 ) were carried out to investigate the influence of fluctuating renewable $\mathrm{H}_{2}$ to FTS. Each campaign consists of a long-term base load and a load change experiment. Müller et al. [24] published five experimental data sets that were validated using process simulation. Gruber et al. [38] published additional experimental data. All test runs were performed with $2.5 \mathrm{~kg}$ of commercial-grade $\mathrm{Co} /$ $\mathrm{Al}_{2} \mathrm{O}_{3}$ catalysts from different suppliers.

Experiments 2 and 3 showed a constant $\alpha$-value comparing load change and base load operation. The $\alpha$-value obtained from experiment 4 shows a slight decrease from 0.88 to 0.87 if load changes were performed. These results indicate that direct supply of renewable $\mathrm{H}_{2}$ in to the FTS biorefinery might be realized without severe changes to the product distribution.
Compared to their associated base load experiments, 2B showed a decrease of $15 \%$, and $3 \mathrm{~B}$ a decrease of $17 \%$ regarding $X_{\mathrm{CO} \text {,reactor }}$ if load changes were performed. Experiment 4B showed stable $X_{\mathrm{CO} \text {,reactor }}$ compared to $4 \mathrm{~A}$. Due to the decreasing $\alpha$-value experiment, $4 \mathrm{~B}$ showed stagnating $\dot{m}_{\mathrm{C} 5+}$ production despite similar $\mathrm{CO}$ conversion and increased load compared to 4A. Thus, a higher share of gaseous FT products was produced in 4B. Furthermore, Müller et al. [24] showed that load changes introduce only marginal temperature deviations to the SBCR.

As part of experiment 4B, Gruber et al. [38] investigated the influence of low and high availability of renewable $\mathrm{H}_{2}$ by applying low and high SV to the SBCR. Table 3 shows the operation conditions applied to perform the low and high SV experiments in the course of experiment 4B. The $72 \mathrm{~h}$ startup phase of the plant, performed at the beginning of each experiment to reach a steady $X_{\mathrm{CO} \text {,reactor, was not included in this }}$ analysis. At high SV, the SBCR feed was increased by $50 \%$ to $7.5 \mathrm{Nm}^{3} / \mathrm{h}$, compared to baseload settings. Low syngas flow on the other hand represents low feedstock availability by decreasing the SBCR feed by $30 \%$ to $3.5 \mathrm{Nm}^{3} / \mathrm{h}$.

Figure 4 shows the experimental results of high and low $\mathrm{SV}$, compared to the associated base and load change experiments. Compared to base load and load change experiments, a slightly higher $\alpha$-value of 0.89 was achieved by applying high SV. This indicates a higher selectivity towards condensable hydrocarbons. Additionally, $\dot{m}_{\mathrm{C} 5+}$ was enhanced by $30 \%$ if $\mathrm{SV}$ was increased. The trade-off by increasing the SV was the decline of $X_{\mathrm{CO} \text {,reactor }}$ to $43 \%$.

The low SV experiment showed an $\alpha$-value of 0.88 , which is slightly lower than at high SV and similar to the chain growth probability at base load settings. By de-

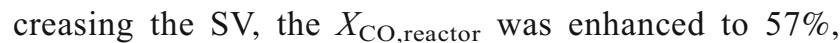
which is an augmentation of $10 \%$ compared to $52 \%$ at base load settings. However, $\dot{m}_{\mathrm{C} 5+}$ was decreased to $0.07 \mathrm{~g} / \mathrm{h} \cdot \mathrm{g}_{\text {catalyst }}$.
Fig. 3 Feed rates applied to the SBCR

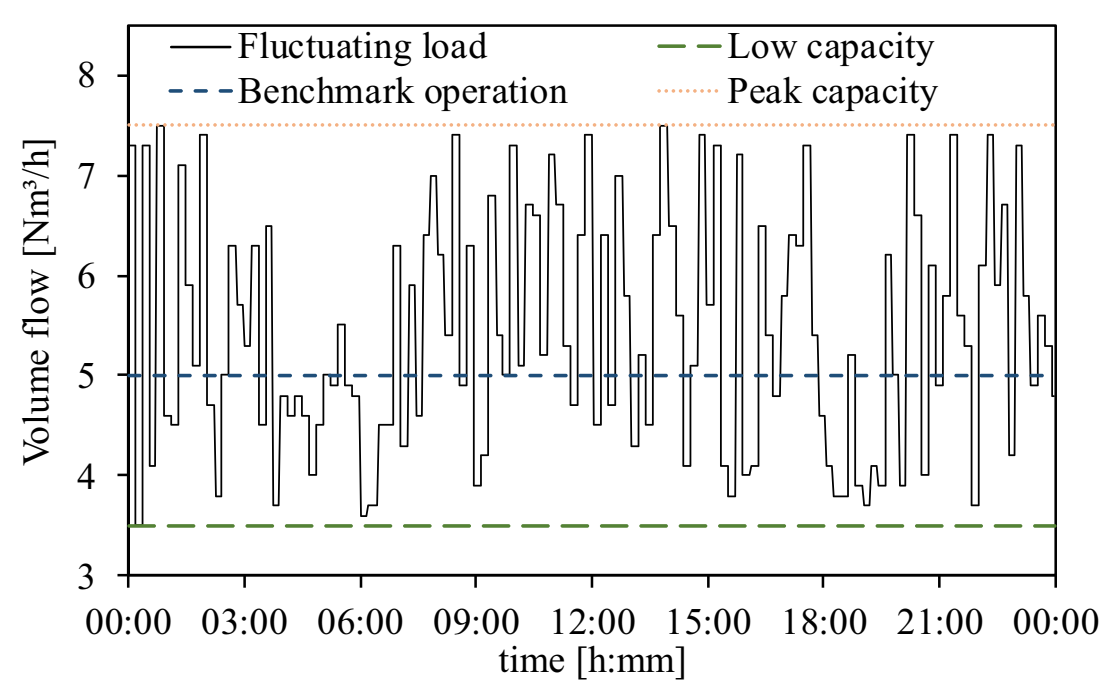


Table 2 Summary of Winddiesel experiments

\begin{tabular}{|c|c|c|c|c|c|c|c|c|}
\hline Parameter & Unit & $\begin{array}{l}\text { Benchmark } \\
{[24]}\end{array}$ & $\begin{array}{l}\text { Base load } \\
{[24]}\end{array}$ & $\begin{array}{l}\text { Load change } \\
{[24]}\end{array}$ & $\begin{array}{l}\text { Base load } \\
{[24]}\end{array}$ & $\begin{array}{l}\text { Load change } \\
{[24]}\end{array}$ & $\begin{array}{l}\text { Base load } \\
{[38]}\end{array}$ & $\begin{array}{l}\text { Load change } \\
\text { [38] }\end{array}$ \\
\hline Experiment & - & 1 & $2 \mathrm{~A}$ & $2 \mathrm{~B}$ & $3 \mathrm{~A}$ & $3 \mathrm{~B}$ & $4 \mathrm{~A}$ & 4B \\
\hline Duration & $\mathrm{h}$ & 1000 & 500 & 500 & 500 & 500 & 500 & 225 \\
\hline SBCR temperature & ${ }^{\circ} \mathrm{C}$ & $230^{1}$ & & & & & & \\
\hline SBCR pressure & barg & $20^{1}$ & & & & & & \\
\hline Catalyst & - & $\mathrm{O}$ & A & A & $\mathrm{B}$ & B & $\mathrm{C}$ & $\mathrm{C}$ \\
\hline $\begin{array}{l}\text { Average SBCR } \\
\text { feed }\end{array}$ & $\mathrm{Nm}^{3} / \mathrm{h}$ & 4.5 & 4.6 & 5.6 & 4.8 & 5.2 & 5.0 & 5.4 \\
\hline SV & $\mathrm{Nl} / \mathrm{h} \cdot \mathrm{g}_{\text {catalyst }}$ & 1.80 & 1.84 & 2.24 & 1.92 & 2.08 & 2.0 & 2.2 \\
\hline $\mathrm{H}_{2} / \mathrm{CO}$ ratio & - & 2.40 & 1.80 & 2.00 & 2.40 & 3.10 & 2.1 & 2.1 \\
\hline$\dot{m}_{\mathrm{C} 5+}$ & $\mathrm{g} / \mathrm{h} \cdot \mathrm{g}_{\text {catalyst }}$ & 0.08 & 0.09 & 0.11 & 0.05 & 0.04 & 0.10 & 0.10 \\
\hline Product $\mathrm{H}_{2} \mathrm{O}$ & $\mathrm{g} / \mathrm{h} \cdot \mathrm{g}_{\text {catalyst }}$ & 0.116 & 0.12 & 0.14 & 0.1 & 0.08 & 0.20 & 0.22 \\
\hline$\alpha$-Value & - & 0.90 & 0.93 & 0.93 & 0.90 & 0.90 & 0.88 & 0.87 \\
\hline$X_{\mathrm{CO}, \text { reactorr }}$ & $\%$ & 32 & 40 & 34 & 12 & 10 & 52 & 52 \\
\hline
\end{tabular}

${ }^{1}$ Values applied in all experiments

Another important factor to evaluate the effects of syngas load changes to the slurry-based FTS reactor is the product analysis regarding substances produced. The main substance classes found were n-paraffins, 1-olefins, and other hydrocarbons (HC). The substance class of other $\mathrm{HC}$ includes mainly i-paraffins and oxygenates. The liquid FTS fraction $\mathrm{C}_{6}-\mathrm{C}_{20}$ was analyzed due to its n-paraffin, 1-olefin, and other $\mathrm{HC}$ content. The solid FTS product $\mathrm{C}_{21+}$ was analyzed regarding n-paraffin and other $\mathrm{HC}$ content. Within the solid fraction, the substance class of other $\mathrm{HC}$ also includes 1-olefins. Figure 5 shows the cumulative substance class distribution of the FTS liquids and solids obtained after 200 operating hours at load change conditions in experiment 4B.

Figure 6 shows the results of the substance class analysis of liquid and solid FT products produced during experiment 4B. Hydrocarbons with a chain length of $\mathrm{C}_{6}$ to $\mathrm{C}_{20}$ were considered as liquid FT syncrude fraction. $\mathrm{C}_{21+}$ hydrocarbons are defined as solid FT fraction.

By applying load changes to the slurry-based FT system, the n-paraffin content rises from 75.3 to $77.7 \mathrm{wt} . \%$ in the liquid product and from 81.2 to $82.2 \mathrm{wt} . \%$ in the solid product, compared to base load operation. The base load experiment showed the lowest and load change experiment and the highest $\mathrm{n}$-paraffin content for both liquid and solid products. The liquid fraction had an $\mathrm{O} / \mathrm{P}$ ratio of 9.69 at load change settings and 7.14 at base load operation. By applying low SV, the liquid and solid FT product had an n-paraffin content of $77.0 \mathrm{wt} . \%$ and $81.7 \mathrm{wt} . \%$, respectively. A P/O ratio of 11.99 was obtained for the liquid FTS fraction at low syngas application. At high SV, a n-paraffin content of 75.9 wt.\% was obtained for liquid FT products and $81.3 \mathrm{wt} . \%$ for $\mathrm{C}_{21+}$ hydrocarbons. The analysis of the liquid FT fraction produced at high SV showed a $\mathrm{P} / \mathrm{O}$ ratio of 6.67 .

\section{Economic assessment}

This chapter summarizes and discusses the economic assessment performed by Zweiler et al. [39]. A sensitivity analysis was performed to evaluate the effects on the economic performance, if key parameters were varied. Based on experimental results and simulations carried out within this project, a flexible economic model was acquired. The aim of this economic
Table 3 Operational settings of low and high SV experiments

\begin{tabular}{llllll}
\hline Parameter & Unit & Low SV [38] & High SV [38] & Load change [38] & Base load [38] \\
\hline Experiment & - & $4 \mathrm{~B}$ & $4 \mathrm{~B}$ & $4 \mathrm{~B}$ & $4 \mathrm{~A}$ \\
SBCR temperature & ${ }^{\circ} \mathrm{C}$ & $230^{1)}$ & & & \\
SBCR pressure & $\mathrm{barg}$ & $20^{1)}$ & & & \\
$\mathrm{SV}$ & $\mathrm{N} / \mathrm{h} \cdot \mathrm{g}_{\text {catalyst }}$ & 1.40 & 3.00 & $1.4-3.0$ & 2 \\
$\mathrm{H}_{2} / \mathrm{CO}$ ratio & - & 2.1 & 2.1 & 2.1 & 2.1 \\
Catalyst & - & $\mathrm{C}^{1}$ & & & 500 \\
Experiment duration & $\mathrm{h}$ & 81 & 26 & 46 & 5 \\
\hline
\end{tabular}

${ }^{1}$ Values applied in all experiments 
Fig. 4 Performance indicating parameter of high and low SV experiments with data from [38]

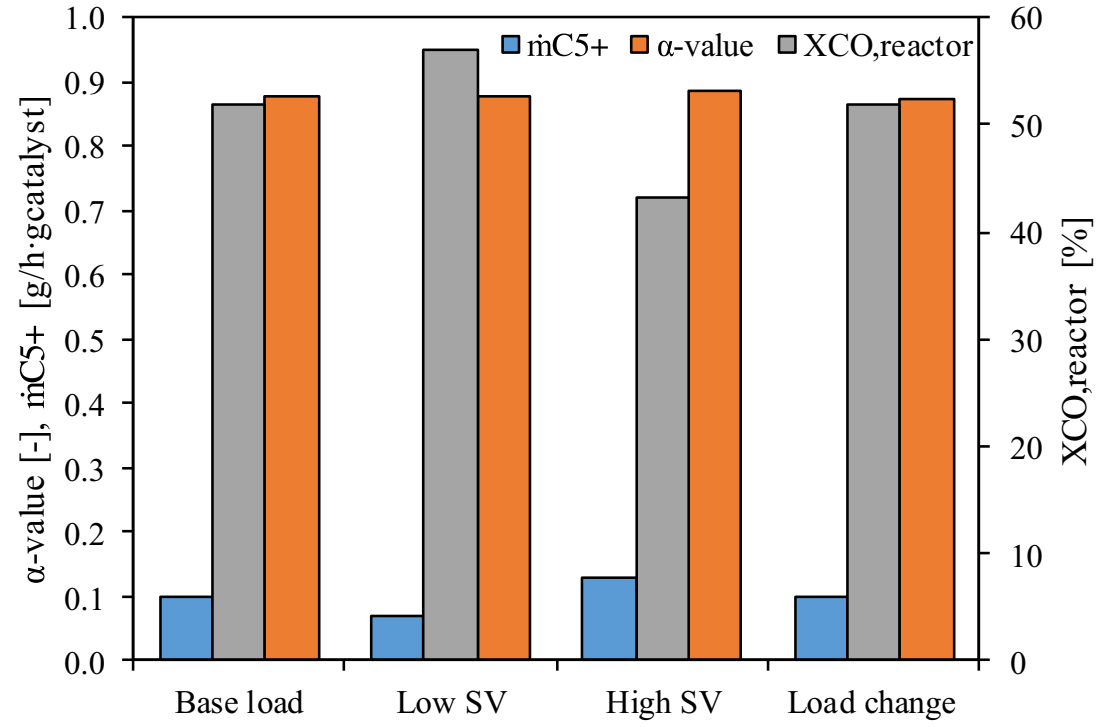

assessment was to evaluate the return on investment (ROI) of commercial Winddiesel biorefineries.

\subsection{Data basis}

The economic assessment includes operating and investment cost of essential plant units. The evaluated process chain includes the lignocellulosic biomass gasification plant, the $\mathrm{H}_{2}$ production via electrolysis, the FT unit, and a steam cycle to convert excess heat to electricity. EC Engineering simulated mass and energy balances used in this assessment. Costs for insurance, wearing parts, maintenance, commodities, credit payback, and operating personnel were summarized as yearly operational costs. To process additional renewable $\mathrm{H}_{2}$, the FT unit is designed to have a capacity of $170 \%$ compared to base load settings. Table 4 shows the assumed FT product distribution and the assumed marked price for the naphtha, diesel, and wax fraction. As can be seen from the table, waxes $\left(\mathrm{C}_{21+}\right)$ are assumed to be the most valuable product. The operating conditions of the FT plant are assumed to be optimized for high wax production [39].

Performance-indicating parameters used in this assessment are summarized in Table 5. Two cases, a $50 \mathrm{MW}_{\text {th }}$ (case A) and a $200 \mathrm{MW}_{\text {th }}$ (case B) fuel input, were investigated. Case A represents a medium-scale biorefinery, producing about $20,000 \mathrm{t}$ of condensable hydrocarbons (naphtha, diesel, and wax) per year. Case B, representing a reasonable upscale to case A, would produce about $88,000 \mathrm{t}$ of condensable hydrocarbons per year. In both cases, a suitable location provides a secure supply of biomass feedstock and excess renewable electricity. Additionally, a suitable setup regarding product monetarization should be located at a close range to minimize
Fig. 5 Exemplary substance class distribution of FTS syncrude, at load change conditions after 200 operating hours

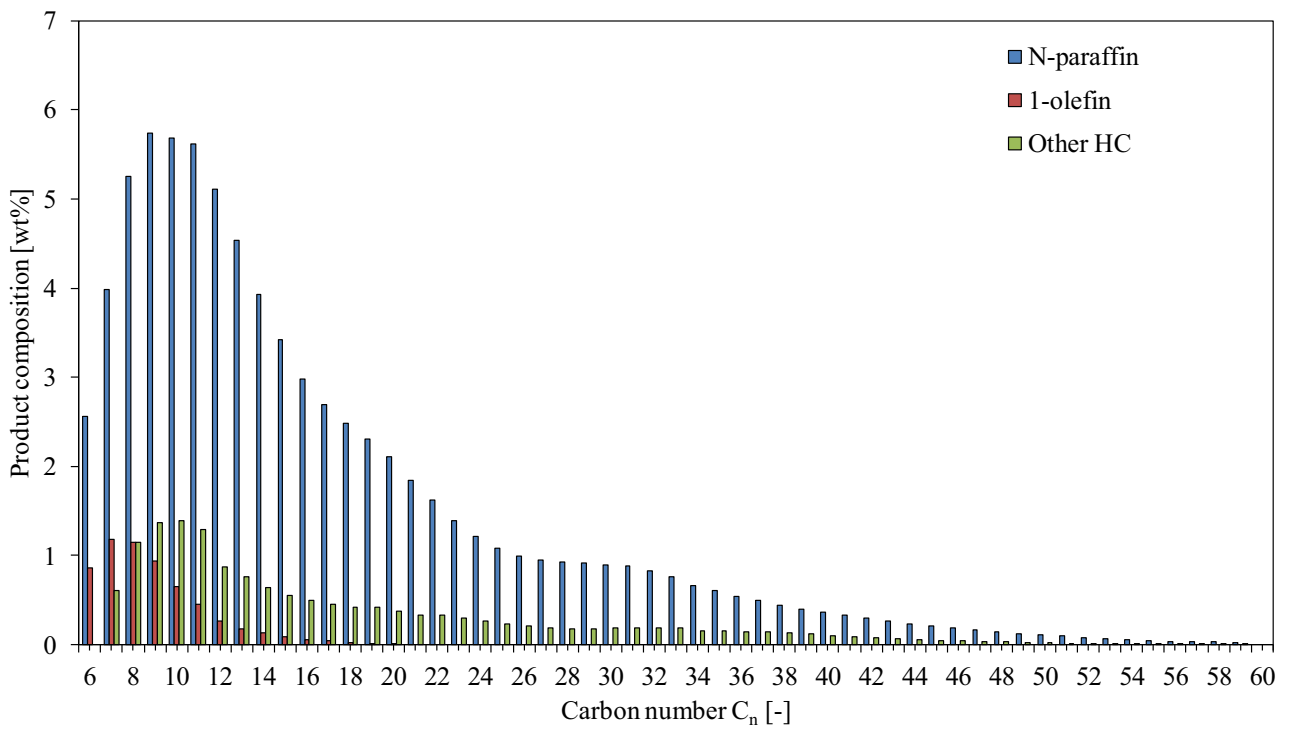




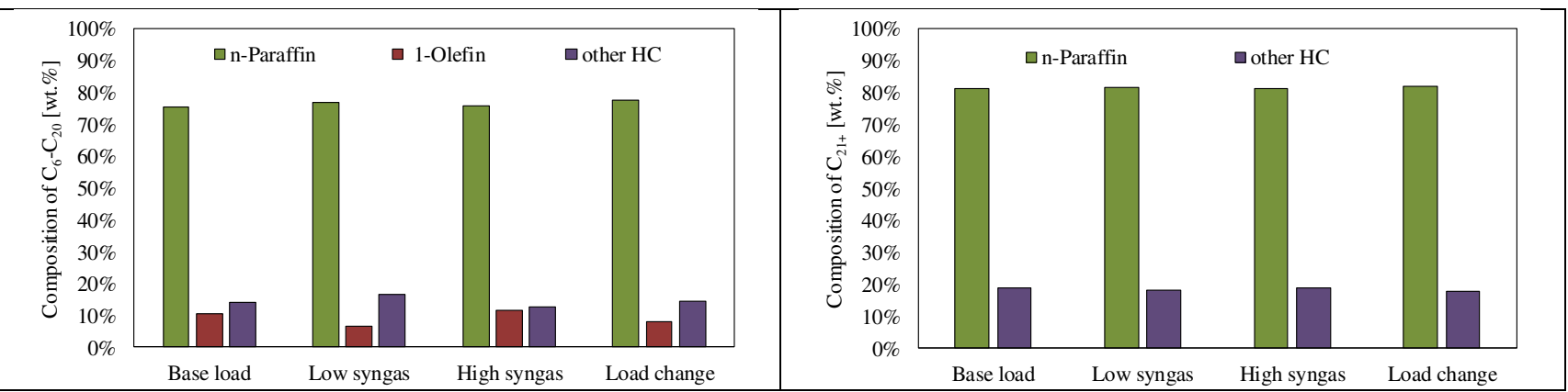

Fig. 6 Composition of liquid (left) and solid (right) FT products (experiments 4A and 4B)

transportation. Strategic factors for biomass conversion sites of similar size compared to the proposed system, such as economics, plant location, and biomass availability, were discussed in further studies [41, 56-60]. The assumption of the costs for excess electricity was based on prices listed at electricity exchanges. Because of the high degree of novelty and the remarkable potential to save $\mathrm{CO}_{2}$ emissions, an investment subsidy rate of $50 \%$ is considered realistic for the first demonstration plant. Furthermore, external financing for investment cost is assumed. Sellable excess electricity, FT products, and oxygen from electrolysis are considered as income [39].

The economic performance was assessed by calculating the ROI (Eq. 8). The yearly profit was calculated by subtracting the operational costs from the income.

$\mathrm{ROI}=\frac{\text { yearly profit }}{\text { investment }- \text { funding }}$

Considering the commercialization of the integrative energy-storing and fuel production concept, it needs to be more profitable than a standalone BtL plant including biomass gasification and FTS. For this reason, the ROI of such a standalone BtL plant was calculated with $8.9 \%$. Subsequently, the breakeven point regarding the integration of excess electricity was evaluated. The breakeven point describes the minimal full-load operating hours necessary, to obtain a ROI equal to the standalone BtL concept. The minimal electrolysis operating hours to gain a ROI of $8.9 \%$ at energy storing modus are listed in Table 5. The full-load operating hours of the electrolysis unit were kept constant for

Table 4 Assumed product distribution and their estimated marked prices [39]

\begin{tabular}{llccl}
\hline Parameter & Unit & FT naphtha & FT diesel & FT waxes \\
\hline Price & EUR/1 & 0.78 & 0.74 & $2^{1}$ \\
Product distribution & wt.\% & 13.00 & 37.35 & 49.65 \\
\hline
\end{tabular}

${ }^{1}$ Price in (EUR/kg) assumption based on [55] each sensitivity analysis performed in this economic assessment.

\subsection{Parameter variation}

To gain insights on how key parameters affect the economic performance of the proposed system, a parameter variation was performed. Table 6 shows the parameters that were considered in this sensitivity analysis. Wood chips with a price of $20 \mathrm{EUR} /$ MWh were assumed as standard fuel input in this assessment. If organic residuals or waste could be utilized to fuel the integrative biorefinery, a much lower fuel price could be assumed. Thus, the fuel price was varied from 0 to $40 \mathrm{EUR} / \mathrm{MWh}$. Feedstock with a price $<15 \mathrm{EUR} / \mathrm{MWh}$ is considered as low-cost feedstock. A price of $40 \mathrm{EUR} / \mathrm{MWh}$ was considered for premium fuels. The uncertainty regarding the price for excess electricity was covered by varying it from -50 to $+50 \mathrm{EUR} / \mathrm{MWh}$. The funding rate was varied from 0 to $70 \%$.

The results achieved by varying the fuel price are shown in Fig. 7 (top-left). Case A showed that, if the fuel price rises to $30 \mathrm{EUR} / \mathrm{MWh}$, a ROI $>6 \%$ could be obtained. Case B showed that, despite that premium fuels are applied, a ROI

Table 5 Data summary used to perform the economic assessment [39]

\begin{tabular}{llll}
\hline Parameter & Unit & Case A & Case B \\
\hline Fuel input & MW & 50 & 200 \\
Water content of wood chips & wt.\% & 40 & 40 \\
Wood chip price & EUR/MWh & 20 & 20 \\
Basis price electricity & EUR/MWh & 70 & 70 \\
Price excess electricity & EUR/MWh & 25 & 25 \\
Full-load hours of FT base load & $\mathrm{h}$ & 7500 & 7800 \\
Full-load hours of electrolysis & $\mathrm{h}$ & 3460 & 4209 \\
El. power input of electrolysis & $\mathrm{MW}$ & 33.5 & 134.1 \\
Electrical own consumption & $\%$ & 10.0 & 8.2 \\
Gasification cold gas efficiency & $\%$ & 70.0 & 70.0 \\
Investment funding & $\%$ & 50.0 & 50.0 \\
Operational costs & $\mathrm{kEUR} / \mathrm{a}$ & 26,552 & 107,275 \\
Income & $\mathrm{kEUR} / \mathrm{a}$ & 33,276 & 143,917 \\
Investment costs & $\mathrm{kEUR}$ & 150,350 & 412,250 \\
\hline
\end{tabular}


Table 6 Parameter variation

\begin{tabular}{lll}
\hline Parameter & Unit & Range \\
\hline Fuel costs & EUR/MWh & 0 to 40 \\
Surplus electricity & EUR/MWh & -50 to 50 \\
Investment funding & $\%$ & 0 to 70 \\
\hline
\end{tabular}

$>10 \%$ could be obtained. The fluctuating excess electricity is designated to power the electrolysis for $\mathrm{H}_{2}$ production. The price for surplus electricity was varied between -50 and 50 EUR/ MWh. The results obtained by varying the price for excess electricity is shown in Fig. 7 (top-right). Case A showed that, if the price for surplus electricity rises to $50 \mathrm{EUR} / \mathrm{MWh}$, a ROI of $6.9 \%$ could be achieved. Moreover, Case B calculated a ROI of $14.1 \%$ if costs for surplus electricity rise to $50 \mathrm{EUR} / \mathrm{MWh}$. To cover uncertainties regarding the funding rate, a parameter
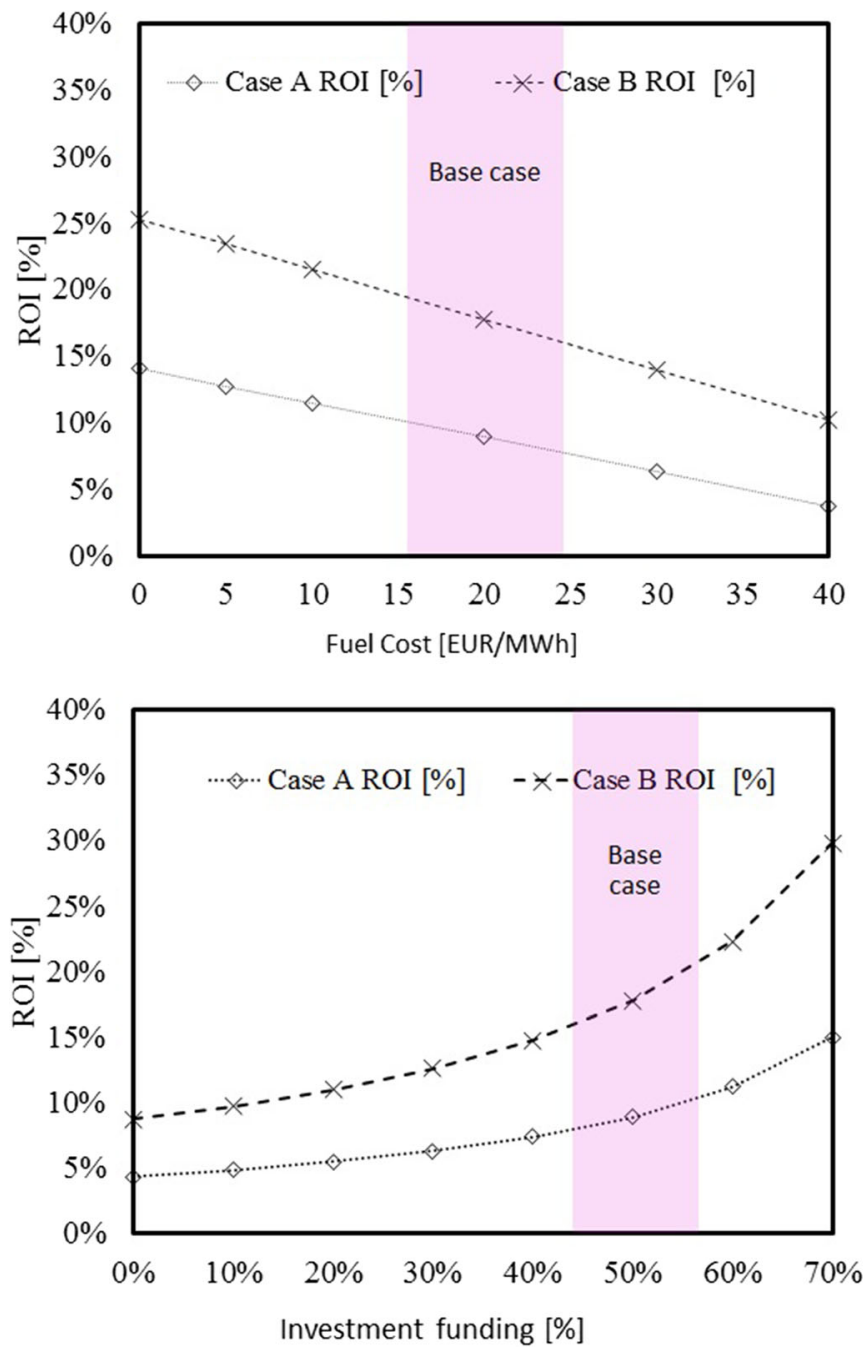

variation from 0 to $70 \%$ investment subsidies was carried out. The results of this variation are shown in Fig. 7 (bottom-left). Case A showed a ROI of $4.4 \%$ and case B a ROI of $8.7 \%$, if no investment subsidies will be granted.

\section{Conclusion}

Within this project, the effects of the fluctuating syngas flow on the FTS performance were investigated. Three long-term campaigns were performed comparing different load regimes applied to the SBCR regarding per-pass CO conversion, productivity, and product distribution. A direct utilization of excess electricity would imply higher and fluctuating loads to the FTS compared to conventional BtL operation.

The high SV experiments showed that an increased load of $50 \%$ in fact decreases the $\mathrm{CO}$ conversion by $17 \%$ but on the contrary increases the productivity by $30 \%$. Considering

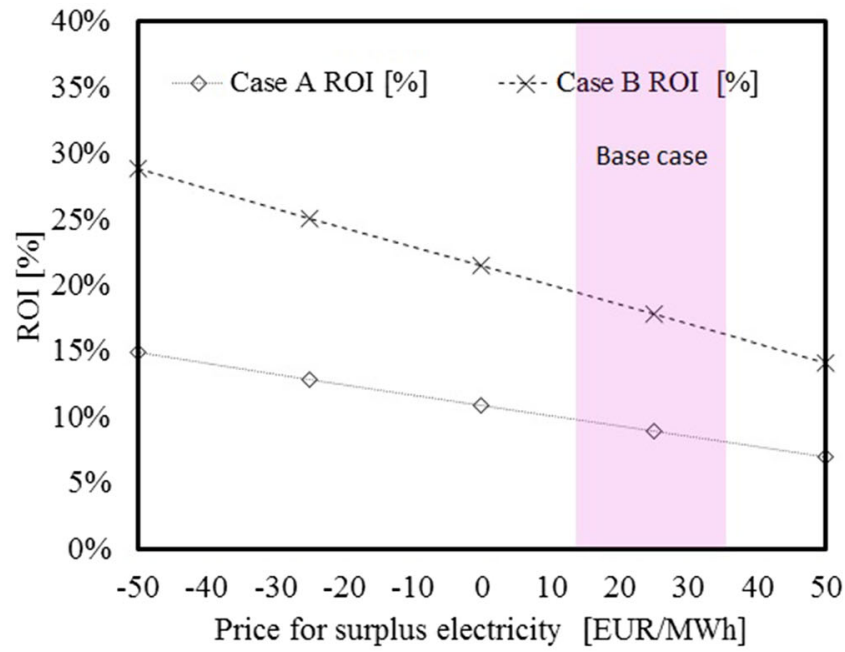

Fig. 7 Economic performance of the proposed biorefinery (top-left: fuel cost variation; top-right: price variation of excess electricity; bottom-left: variation of investment funding, based on data from [39]) 
experiment 2 , the analysis of the chain growth probability factor $\alpha$ showed similar results in all performed operation modes. A per-pass CO conversion of up to $57 \%$ was reported at low SV settings. The substance class analysis showed that the solid FT products have a higher n-paraffin share compared to liquid FT products. In the solid FT fraction, a n-paraffin of up to $82.2 \mathrm{wt} . \%$ was determined, whereas in the liquid fraction the maximal reported $\mathrm{n}$-paraffin was $77.7 \mathrm{wt} . \%$. The $\mathrm{P} / \mathrm{O}$ ratio of the liquid FT product was determined between 6.67 and 11.99. By comparing the performance of the applied commercial-grade cobalt-based FT catalysts, it became obvious that catalyst choice will be a major factor towards a stable and economic plant operation. This experimental work indicates that the utilization of excess electricity via electrolysis, $\mathrm{CO}_{2}$ gasification, and FTS could increase the productivity compared to conventional $\mathrm{BtL}$ operation and at the same time maintain the product distribution in the same range.

The improvement of fuel flexibility will be one of the main economic challenges for industrial gasification plants in the future. Lignocellulosic residues, sewage sludge, or plastic residues might be easily obtainable, low-cost feedstock alternatives. Germany, for example, produced about 1.7 million tons of sewage sludge (dry substance) in 2017 [61]. Additional 27.1 million tons of plastic waste was generated in Europe in 2016 [62]. However, the challenges of the utilization of plastic were reviewed by Lopez et al. [63]. Increasing costs for waste management and waste disposal, if not prohibited by law, might be a benefactor that promotes the utilization of these materials via gasification [64]. The applicability of gases produced by sewage sludge or plastic gasification [64-66] for FTS needs to be evaluated in further research work. A suitable location providing secure access to low-cost gasification feedstock and nearby product consumers might be municipal waste management facilities. It seems realistic that investment funding will be granted to a demonstration plant. However, follow-up plants are not expected to be subsidized. Thus, the $0 \%$ investment funding case should be considered regarding further investments.

The experimental work and the economic assessment indicate that the utilization of excess electricity improves the productivity of the proposed biorefinery, compared to conventional BtL FT setups. Further experimental work should evaluate the benefit of adding a gas loop and a steam reformer to the FT unit. Additionally, the feasibility to implement a RWGS unit to utilize surplus $\mathrm{CO}_{2}$ should be investigated.

Symbols $\alpha$ chain growth probability

$W_{n}$ mass fraction of hydrocarbons with $n$ carbon atoms

$n_{i}$ moles of substance $i$

$m_{i}$ mass of substance $i$

$\dot{m}_{i}$ mass flow of substance $i$

Acknowledgments The project Winddiesel_klienIF is executed in cooperation with Energie Burgenland AG, Bilfinger Bohr- und Rohrtechnik
GmbH, Güssing Energy Technologies GmbH, REPOTEC GmbH \& Co $\mathrm{KG}$, Energy \& Chemical Engineering $\mathrm{GmbH}$, and the Institute of Chemical Engineering from TU WIEN.

Funding information Open access funding provided by TU Wien (TUW). This study was financially supported by the Austrian government through the "Klima- und Energiefonds"-financed Project Winddiesel_ klienIF within the "e!Mission.at" funding scheme.

Open Access This article is distributed under the terms of the Creative Commons Attribution 4.0 International License (http:// creativecommons.org/licenses/by/4.0/), which permits unrestricted use, distribution, and reproduction in any medium, provided you give appropriate credit to the original author(s) and the source, provide a link to the Creative Commons license, and indicate if changes were made.

\section{References}

1. Masson-Delmotte V, Zhai P, Pörtner H-O, Roberts D, Skea J, Shukla PR, Pirani A, Moufouma-Okia W, Péan C, Pidcock R, Connors S, Matthews JBR, Chen Y, Zhou X, Gomis MI, Lonnoy E, Maycock T, Tignor M (2018) IPPC - Summary for Policymakers. In: Global Warming of $1.5^{\circ} \mathrm{C}$. An IPCC Special Report on the impacts of global warming of $1.5^{\circ} \mathrm{C}$ above preindustrial levels and related global greenhouse gas emission pathways, in the context of strengthening the global resp. World Meteorological Organization, Geneva

2. United Nations (2019) The Katowice climate package: making the Paris Agreement work for all. https://unfccc.int/process-andmeetings/the-paris-agreement/katowice-climate-package. Accessed 6 Mar 2019

3. BMWi (2019) "Anteil Erneuerbarer Energien an der Energieversorgung in Deutschland nach Bereichen im Jahresvergleich 2007 und 2017." - Statista - Das Statistik-Portal, Statista. de.statista.com/statistik/daten/studie/153098/umfrage/ anteil-erneuerbarer-energien-zur-energiebereitstellung/. Accessed 6 Mar 2019

4. Krylova AY (2014) Products of the Fischer-Tropsch synthesis (a review). Solid Fuel Chem 48:22-35. https://doi.org/10.3103/ S0361521914010030

5. Lappas A, Heracleous E (2016) Chapter 18 - production of biofuels via Fischer-Tropsch synthesis: biomass-to-liquids. In: Luque R, Lin C, Wilson K, Clark J (eds) Handbook of biofuels production processes and technologies, 2nd edn. Elsevier Ltd, Amsterdam, pp 549-593

6. Ail SS, Dasappa S (2016) Biomass to liquid transportation fuel via Fischer Tropsch synthesis - technology review and current scenario. Renew Sust Energ Rev 58:267-286. https://doi.org/10.1016/j.rser. 2015.12.143

7. Dry ME (2002) High quality diesel via the Fischer-Tropsch process - a review. J Chem Technol Biotechnol 77:43-50. https://doi.org/ $10.1002 /$ jctb. 527

8. Schablitzky HW, Lichtscheidl J, Hutter K, Hafner C, Rauch R, Hofbauer H (2011) Hydroprocessing of Fischer-Tropsch biowaxes to second-generation biofuels. Biomass Convers Biorefinery 1:2937. https://doi.org/10.1007/s13399-010-0003-x

9. Leckel D, Liwanga-Ehumbu M (2006) Diesel-selective hydrocracking of an iron-based Fischer-Tropsch wax fraction (C15 -C45) using a MoO3-modified noble metal catalyst. Energy Fuel 20:2330-2336. https://doi.org/10.1021/ef060319q 
10. Blakey S, Rye L, Wilson CW (2011) Aviation gas turbine alternative fuels: a review. Proc Combust Inst 33:2863-2885. https://doi. org/10.1016/j.proci.2010.09.011

11. Hudson L, Jefferson A, Bauen A, Nattrass L (2016) Chapter 14 sustainable aviation: a UK roadmap for sustainable aviation fuels. In: Biofuels for aviation, pp 315-337

12. de Klerk A (2011) Part IV : synthetic transportation fuels: chapter 13-15. In: Fischer-Tropsch refining, pp 249-299

13. de Klerk A (2011) Part V : refining technology: chapter 16-23. In: Fischer-Tropsch Refining, pp 301-487

14. IEA Renewables 2018 - Market analysis and forecast from 2018 to 2023 - Power. https://www.iea.org/renewables2018/power/. Accessed 6 Mar 2019

15. Mazza A, Bompard E, Chicco G (2018) Applications of power to gas technologies in emerging electrical systems. Renew Sust Energ Rev 92:794-806. https://doi.org/10.1016/j.rser.2018.04.072

16. Gahleitner G (2013) Hydrogen from renewable electricity : an international review of power-to-gas pilot plants for stationary applications. Int J Hydrog Energy 38:2039-2061. https://doi.org/10. 1016/j.ijhydene.2012.12.010

17. Kraftfahr-Bundesamt Bestand an Pkw in den Jahren 2009 bis 2018 nach ausgewählten Kraftstoffarten. https://www.kba.de/DE/ Statistik/Fahrzeuge/Bestand/Umwelt/b_umwelt_z.html?nn= 663524. Accessed 6 Mar 2019

18. Groß P, Rauch R, Hofbauer H, Aichernig C, Zweiler R (2015) Winddiesel technology - an alternative to power to gas systems. Proc EUBCE 23. doi: https://doi.org/10.5071/23rdEUBCE2015ICV.4.17

19. Jeremiás M, Pohorely M, Svoboda K, Manovic V, Anthony EJ, Skoblia S, Beno Z, Šyc M (2017) Gasification of biomass with $\mathrm{CO} 2$ and $\mathrm{H} 2 \mathrm{O}$ mixtures in a catalytic fluidised bed. Fuel 210: 605-610. https://doi.org/10.1016/j.fuel.2017.09.006

20. Valin S, Bedel L, Guillaudeau J, Thiery S, Ravel S (2016) CO2 as a substitute of steam or inert transport gas in a fluidised bed for biomass gasification. FUEL 177:288-295. https://doi.org/10.1016/ j.fuel.2016.03.020

21. Stec M, Czaplicki A, Tomaszewicz G, Słowik K (2018) Effect of $\mathrm{CO} 2$ addition on lignite gasification in a CFB reactor : a pilot-scale study. Korean J Chem Eng 35:129-136. https://doi.org/10.1007/ s11814-017-0275-y

22. Jeremiás M, Pohorely M, Svoboda K, Skoblia S, Beno Z, Šyc M (2018) CO2 gasification of biomass : the effect of lime concentration in a fluidised bed. Appl Energy 217:361-368. https://doi.org/ 10.1016/j.apenergy.2018.02.151

23. Pastor-Pérez L, Baibars F, Le Sache E, Arellano-García H, Gu S, Reina TR (2017) CO2 valorisation via reverse water-gas shift reaction using advanced $\mathrm{Cs}$ doped $\mathrm{Fe}-\mathrm{Cu} / \mathrm{Al} 2 \mathrm{O} 3$ catalysts. J CO2 Util 21:423-428. https://doi.org/10.1016/j.jcou.2017.08.009

24. Müller S, Groß P, Rauch R, Zweiler R, Aichernig C, Fuchs M, Hofbauer H (2018) Production of diesel from biomass and wind power - energy storage by the use of the Fischer-Tropsch process. Biomass Convers Biorefinery 8:275-282. https://doi.org/10.1007/ s13399-017-0287-1

25. Nikparsa P, Mirzaei AA, Rauch R (2016) Impact of Na promoter on structural properties and catalytic performance of $\mathrm{CoNi} / \mathrm{Al} 2 \mathrm{O} 3$ nanocatalysts for the $\mathrm{CO}$ hydrogenation process: Fischer-Tropsch technology. Catal Lett 146:61-71. https://doi.org/10.1007/s10562015-1620-6

26. Sabatier P, Senderens JB (1902) New synthesis of methane. C R Hebd Seances Acad Sci 134:514-516

27. Fischer F, Tropsch H (1923) Über die Herstellung synthetischer Ölgemische (Synthol) durch Aufbau aus Kohlenoxyd und Wasserstoff. Brennstoff-Chemie 4:276-285

28. Steynberg AP (2004) Chapter 1 - introduction to Fischer-Tropsch technology. In: Steynberg AP, Dry ME (eds) Fisceher-Tropsch technology. Elsevier Science \& Technology Books, Amsterdam, pp 1-63

29. Schulz H (1999) Short history and present trends of FischerTropsch synthesis. Appl Catal A Gen 186:3-12. https://doi.org/ 10.1016/S0926-860X(99)00160-X

30. Anderson RB (1956) Catalysis Vol. IV - hydrocarbon synthesis, hydrogenation and cyclization - chapter 1-3. Reinhold Publishing Corp, New York

31. de Klerk A (2011) Chapter 4 - Fischer-Tropsch synthesis. In: Fischer-Tropsch Refining. Wiley-VCH Verlag \& Co. KGaA, Hoboken, pp 73-104

32. Sauciuc A, Abosteif Z, Weber G, Potetz A, Rauch R, Hofbauer H, Schaub G, Dumitrescu L (2012) Influence of operating conditions on the performance of biomass-based Fischer- Tropsch synthesis. Biomass Convers Biorefinery 2:253-263. https://doi.org/10.1007/ s13399-012-0060-4

33. Yong-Wang L, de Klerk A (2013) Chapter 5 - industrial case studies. In: Maitlis PM, de Klerk A (eds) Greener Fischer-Tropsch processes for fuels and feedstocks. Wiley-VCH Verlag \& Co. KGaA, Hoboken, pp 107-128

34. de Klerk A, Maitlis PM (2013) Chapter 4 - what can we do with Fischer-Tropsch products? In: Maitlis PM, de KA (eds) Greener Fischer-Tropsch processes for fuels and feedstocks. Wiley-VCH Verlag \& Co. KGaA, Hoboken, pp 81-106

35. Gu B, Khodakov AY, Ordomsky VV (2018) Selectivity shift from paraffins to a -olefins in low temperature Fischer-Tropsch synthesis in the presence of carboxylic acids. Chem Commun 54:2345-2348. https://doi.org/10.1039/c7cc08692j

36. NULL VK (2006) Patent : WO2006122979 - use of a FischerTropsch derived white oil in food contact applications - Shell Internationale Research Maatschappij BV, pp 1-26

37. Bekker M, Louw NR, Van RVJJ, Potgieter J (2013) The benefits of Fischer-Tropsch waxes in synthetic petroleum jelly. Int J Cosmet Sci 35:99-104. https://doi.org/10.1111/ics.12011

38. Gruber H, Groß P, Reichhold A, Reinhard R, Abualmfalfel R, Zweiler R, Aichernig C, Weber G, Loipersböck J, Binder M (2018) Laboratory scale experiments and evaluation of FischerTropsch - Winddiesel experiments. Proc 6th Annu Int Conf Chem Chem Eng Chem process - CCECP 2018. https://doi.org/10.5176/ 2301-3761_CCECP18.14

39. Zweiler R, Goritschnig M, Kreuter K, Novakovits P, Pomper M, Hofbauer H, Groß P, Rauch R, Aichernig C, Müller S, Bosch K, Haider M (2017) Untersuchung des Lastwechselverhaltens eines Slurryreaktors zur Einkopplung von H2 und Produktion von FTDiesel. http://winddiesel.at/images/Downloads/13003-BB006a Publizierbarer_endbericht_Winddiesel_klienIF.pdf. Accessed $\overline{6}$ Mar 2019

40. Naik SN, Goud VV, Rout PK, Dalai AK (2010) Production of first and second generation biofuels: a comprehensive review. Renew Sust Energ Rev 14:578-597. https://doi.org/10.1016/j.rser.2009.10. 003

41. Kallio AMI, Chudy R, Solberg B (2018) Prospects for producing liquid wood-based biofuels and impacts in the wood using sectors in Europe. Biomass Bioenergy 108:415-425. https://doi.org/10. 1016/j.biombioe.2017.11.022

42. Buchspies B, Kaltschmitt M (2018) A consequential assessment of changes in greenhouse gas emissions due to the introduction of wheat straw ethanol in the context of European legislation. Appl Energy 211:368-381. https://doi.org/10.1016/j.apenergy.2017.10. 105

43. Tsalidis GA, El DF, Korevaar G, Haije W, de Jong W, Kiel J (2017) An LCA-based evaluation of biomass to transportation fuel production and utilization pathways in a large port's context. Int J Energy Environ Eng 8:175-187. https://doi.org/10.1007/s40095-0170242-8 
44. Cherubini F, Bird ND, Cowie A, Jungmeier G, Schlamadinger B, Woess-Gallasch S (2009) Energy- and greenhouse gas-based LCA of biofuel and bioenergy systems: key issues, ranges and recommendations. Resour Conserv Recycl 53:434 447. https://doi.org/ 10.1016/j.resconrec.2009.03.013

45. Hjuler SV, Hansen SB (2018) LCA of biofuels and biomaterials. In: Hauschild MZ, Rosenbaum RK, Olsen SI (eds) Life cycle assessment. Springer International Publishing, Cham, pp 755-782

46. European Union (2018) Directive (EU) 2018/2001 of the European Parliament and of the Council of 11 December 2018 on the promotion of the use of energy from renewable sources (recast)

47. European Commission. (2015) Directive 2015/1513 of the European Parliament and of the Council of 9 September 2015 amending Directive 98/70/EC relating to the quality of petrol and diesel fuels and amending Directive 2009/28/EC on the promotion of the use of energy from renewable sou

48. Bohlhar-Nordenkampf M, Rauch R, Bosch K, Aichernig C, Hofbauer H (2002) Biomass CHP plant Güssing - using gasification for power generation. Int Conf Biomass Util

49. Hofbauer H, Rauch R, Bosch K, Koch R, Aichernig C (2002) Biomass CHP plant Güssing - a success story. In: Expert meet pyrolysis Gasif biomass waste, pp 527-536

50. Bolhàr-Nordenkampf $\mathrm{M}$, Hofbauer H (2004) Gasification demonstration plants In Austria. IV International Slovak Biomass forum, Bratislava 1:227-230. https://doi.org/10.13140/2.1.4084.1280

51. Sauciuc A, Potetz A, Weber G, Rauch R, Hofbauer H, Dumitrescu L (2011) Synthetic diesel from biomass by Fischer-Tropsch synthesis. Renew Energy Power Qual J 1:337-342. https://doi.org/10. 24084/repqj09.328

52. Sauciuc A (2012) Biocombustible materials obtained from biomass using cobalt based catalysts - PhD Thesis Transilvania University of Brasov

53. Gruber H, Groß P, Rauch R, G. Weber, Loipersböck J, Niel J, Wahringer D, Reichhold A, Hofbauer H, Zweiler R, Aichernig C (2017) Fischer-Tropsch synthesis - effects of feedstock load changes regarding product quality and catalyst attrition. Proc EUBCE 25. https://doi.org/10.5071/25thEUBCE2017-3AO.9.4

54. Rauch R, Kiennemann A, Sauciuc A (2013) Chapter 12 - FischerTropsch synthesis to biofuels (BtL process). In: Triantafyllidis K, Lappas A, Ströcker M (eds) The role of catalysis for the sustainable production of bio-fuels and bio-chemicals. Elsevier B.V., Amsterdam, pp 397-443

55. Jensen KL, Menard JR, English BC (2013) Market analysis for Fischer-Tropsch waxes

56. Hannula I, Kurkela E (2013) Liquid transportation fuels via largescale fluidised-bed gasification of lignocellulosic biomass - online report. https://www.vtt.fi/inf/pdf/technology/2013/T91.pdf. Accessed 17 June 2019
57. Thunman H, Gustavsson C, Larsson A, Gunnarsson I, Tengberg F (2019) Economic assessment of advanced biofuel production via gasification using cost data from the GoBiGas plant. Energy Sci Eng 7:217-229. https://doi.org/10.1002/ese3.271

58. Dutta A, Talmadge M, Hensley J, Worley M, Dudgeon D, Barton D, Groendijk P, Ferrari D, Stears B, Searcy E, Wright C, Hess J (2011) Process design and economics for conversion of lignocellulosic biomass to ethanol - thermochemical pathway by indirect gasification and mixed alcohol synthesis - online report. https:// www.nrel.gov/docs/fy11osti/51400.pdf. Accessed 17 June 2019

59. Brynolf S, Taljegard M, Grahn M, Hansson J (2018) Electrofuels for the transport sector: a review of production costs. Renew Sust Energ Rev 81:1887-1905. https://doi.org/10.1016/j.rser.2017.05. 288

60. Natarajan K, Leduc S, Pelkonen P, Tomppo E, Dotzauer E (2014) Optimal locations for second generation Fischer Tropsch biodiesel production in Finland. Renew Energy 62:319-330. https://doi.org/ 10.1016/j.renene.2013.07.013

61. Bundesministerium für Umwelt Naturschutz und nukleare Sicherheit (BMU) Statistiken Klärschlamm. https://www.bmu.de/ themen/wasser-abfall-boden/abfallwirtschaft/statistiken/ klaerschlamm/. Accessed 21 May 2019

62. PlasticsEurope Kunststoffabfallaufkommen und recycelte Menge Kunststoff in Europa in den Jahren 2006 bis 2016 (in Millionen Tonnen). https:/de.statista.com/statistik/daten/studie/206843/ umfrage/kunststoffabfallaufkommen-und-recycelte-mengekunststoff-in-europa/. Accessed 21 May 2019

63. Lopez G, Artetxe M, Amutio M, Alvarez J, Bilbao J, Olazar M (2018) Recent advances in the gasification of waste plastics. A critical overview. Renew Sust Energ Rev 82:576-596. https://doi. org/10.1016/j.rser.2017.09.032

64. Judex JW, Gaiffi M, Burgbacher HC (2012) Gasification of dried sewage sludge: status of the demonstration and the pilot plant. Waste Manag 32:719-723. https://doi.org/10.1016/j.wasman. 2011.12.023

65. Schmid JC, Wolfesberger U, Koppatz S, Pfeifer C, Hofbauer H (2011) Variation of feedstock in a dual fluidized bed steam gasifier - influence on product gas, tar content, and composition. Spec issue TC. Biomass 31:205-215. https://doi.org/10.1002/ep. 11607

66. Kern SJ, Pfeifer C, Hofbauer H (2013) Cogasification of polyethylene and lignite in a dual fluidized bed gasifier. Ind Eng Chem Res 52:4360-4371. https://doi.org/10.1021/ie303453e

Publisher's note Springer Nature remains neutral with regard to jurisdictional claims in published maps and institutional affiliations. 